\title{
Dry Ports in China and West Africa: A Comparative Study
}

\author{
Hamadou Tahirou Abdoulkarim¹, Seydou Harouna Fatouma ${ }^{2}$, Elijah Musango Munyao ${ }^{3}$ \\ ${ }^{1}$ School of Economics and Management, Shanghai Maritime University, Shanghai, China \\ ${ }^{2}$ Glorious Sun School of Business and Management, Donghua University, Shanghai, China \\ ${ }^{3}$ Merchant Marine College, Shanghai Maritime University, Shanghai, China \\ Email: kalishufe@hotmail.com, sfatouka@gmail.com, elimunyao@gmail.com
}

How to cite this paper: Abdoulkarim, H.T., Fatouma, S.H. and Munyao, E.M. (2019) Dry Ports in China and West Africa: A Comparative Study. American Journal of Industrial and Business Management, 9, 448-467.

https://doi.org/10.4236/ajibm.2019.93030

Received: January 27, 2019

Accepted: March 11, 2019

Published: March 14, 2019

Copyright (c) 2019 by author(s) and Scientific Research Publishing Inc. This work is licensed under the Creative Commons Attribution International License (CC BY 4.0).

http://creativecommons.org/licenses/by/4.0/

\begin{abstract}
The dry port concept was first adopted in Europe and North America, followed by Asia, South America and then Africa. Since then, the development of inland cargo distribution facilities has been an active approach to support the hinterlands of maritime gateways among other functions. Dry ports can be developed in the hinterland based on different approaches, involving differing functions, actors, motivations and logistical models. They can be classified as close, mid-range or distant, with respect to the seaport. Dry port development can be carried out by port authorities, port terminal operators and transport providers such as third-party logistics providers or rail operators or by public bodies: local, national or regional. One of the design strategies for these facilities is rail-based which promotes economies of scale on high capacities and long distance links. The other strategy is the road-based short-distance satellite terminals aimed at decongesting the port or facilitating faster custom clearances. This paper carries out a comparative analysis of dry ports in China and the West African countries using a descriptive approach and providing case studies for each parameter used in the comparative study. This study is based on motivations for dry port development in these regions, as well as the development and management models applied in the dry port sector. In addition, a discussion on the merits and demerits of the management and development models applied on dry ports in these regions are also included in this study, from which conclusions and recommendations are drawn to support policy formulation and future studies. This paper not only serves to contribute to the existing academic knowledge on dry ports, but also provides the policy makers and practitioners in the logistics and trade sectors with an invaluable opportunity to compare the practices in the two regions for application to appropriate scenarios.
\end{abstract}




\section{Keywords}

Dry Ports, Development Models, Governance, China, West Africa

\section{Introduction}

Dry Ports are developed from scratch from an existing inland terminal through availing additional facilities that convert the inland terminals into dry ports. According to [1], if an inland terminal has a direct connection to a seaport either through a road or rail, the terminal has a high capacity traffic mode (rail) and if the terminal offers similar facilities to those available at a seaport, then it can be regarded as a dry port.

The availability of custom services at the dry port ensures that goods are cleared and made ready for overseas transportation at the dry port. This ensures that already cleared cargo is loaded directly onto the ship at the seaport with minimal waiting time. The same case is also applicable to imported cargo which is loaded onto the available transportation means directly to the dry ports, hence easing the congestion at the port and consequently enhancing seaport capacity. From the previous research works on this area, it was found that there was no comparative study on dry port development between a developed country like China and developing countries in the West African region. This paper aims at bridging this gap by using a descriptive approach to carry out a comparative study of the situation of dry port development in China and West Africa, providing specific case studies. A comparative study between dry ports in China and West African countries would be very useful because of the following reasons. First, comparatively, the development of dry ports in China is at a more advanced stage compared to that in the West African countries, where, although the concept was introduced a few years back, it started to receive the much needed attention just recently. Hence, from this comparison, the West African countries could acquire invaluable lesson from China's experience and determine what can be sustainably applied in their case. Secondly, in the recent past, China has become a major financial partner in most projects, not only in West Africa, but also across Africa as a continent [2]. As such, it is imperative for the West African countries to have adequate knowledge of the development and governance models that have been used in China. This knowledge is useful to enable the governments to monitor the dry port projects and also offer suggestions in the process of this development. Finally, the comparative description will be a valuable tool in policy formulation and setting up of relevant management bodies to aid in the future developments and operations of the dry ports in the West African region. This is applicable, for instance, after the projects have been transferred back to the respective governments in cases where the Build, Own, Operate, Transfer (BOOT) or the build, Operate, Transfer (BOT) models have been used in the development of the dry ports. 


\section{Literature Review}

A number of definitions for a dry port have been put forward by different researchers derived from the perspective of the physical facility, purpose and function [3]. One of the definitions was put forward by Leveque and Roso [4], where a dry port is defined as "an inland intermodal terminal directly linked to seaport(s) with high capacity transport means, where customers can leave or pick up their standardized unit as if directly as a seaport". In this definition, a dry port does not only perform the well know role of being a transshipment facility, similar inland terminals, but also provides other services such as; cargo consolidation, storage of both cargo and empty containers, customs clearance as well as repair and maintenance of containers. Wang and Wei [5] added cargo distribution to the list of functions performed by a dry port. Another definition of a dry port was put forward by the United Nations Conference on Trade and Development (UNCTAD, 1991). In this work, a dry port is defined as "a common user facility with public authority status, equipped with fixed installations and offering services for handling and temporary storage of any kind of goods, including containers carried under customs transit by any applicable mode of transport, placed under customs' control and with customs and other agencies competent to clear goods for home use, ware housing, temporary admissions, re-export, temporary storage for onward transit and outright export".

Gerald and Jin [3] undertook a study on dry ports in China and East Africa based on historical perspectives, development and management models. They concluded that dry port creation can result to increased employment opportunities to the local population, improved economic fortunes of a place as well as opening up disconnected hinterlands to development as observed in the case of China. To include a multiple criteria in evaluating location of dry ports in the developing countries, Nguyen and Nottenbom [6] presented a conceptual framework from a multiple stakeholder perspective supported by a case study of Vietnam. In order to understand the development paths for China's dry ports Beresford et al. [7] reviewed the existing logistics in institutional and dry port development. From their work, it can be deduced that motivations behind the development of dry ports vary among regions. The motivations, opportunities and challenges of dry port development in china are discussed by [8] [9], dealt with the status of dry ports in the North America and Europe. In their work, they concentrated on the rail-based dry port development criteria and portray the two regions as being comparatively different based on motivations for the dry port development and challenges experienced in these ventures. The motivations behind dry port development in land locked countries, more specifically in West Africa, are enumerated in [10]. It is important to note that, the research works reviewed for this paper, show that inland consumption and logistics cost reduction are common factors motivating dry port development in most regions. 


\section{Motivations for Dry Port Development}

A dry port development is influenced by efficiency and availability of transport modes, availability of a market function and its intensity, as well governance and regulatory framework [11]. Geographical characteristics supported by modal availability, like rail and road, as well as the ease of inland access greatly influence the emergence and development of dry ports [11].

A dry port is a facility highly integrated within the supply chain management practices. This integration may take different forms, such as the clustering of freight distribution centers, container depots, custom clearance and third-party logistics services. A dry port can also act as a buffer in supply chains. This could be in the form of a temporary warehousing facility, ordinarily connected to warehouse planning systems of the proximate distribution centers [12].

In some instances, the development of dry ports highlights gaps in conventional inland freight distribution that require mitigation measures as illustrated in Figure 1. First, the intensified activities at the main seaport facility with a limited land availability for expansion prompt search for lower valued land locations to support less demanding freight activities.

Secondly, the seaport capacity inadequacy is another major reason for development of a dry port. The intensive economic growth with increasing goods' flow has not only resulted to growing road traffic in most ports world over, but has also led to intensified maritime traffic. Consequently, most ports face similar challenges of the capacity inadequacy or lack of efficiency [9]. The solution to ports' congestion problem, as recommended by industry stakeholders, would be expansion of seaport terminals by the water, to cope with the ever increasing imports of manufactured goods, notably from China. However, the strategy which would involve port infrastructural development by the water is not viable. Thus, this prompts the port authorities think of for alternative ways to mitigate the seaport congestion challenge [9]. It has been shown that a system of inland port terminals would increase the intermodal capability of hinterland freight distribution. The third reason is that dry ports have been found to offer relatively higher levels of accessibility resulting from lower costs of distribution with improved capacities via the long distance transport corridors. These inland transportation corridors provide an avenue for ports to extend into the local hinterland of competing ports there by extending their cargo base. The fourth major factor that promote dry port concept is to do with environmental challenges associated with cargo haulage activities. An efficient transportation network is invaluable for economic growth and an important asset in international competition. However, transport operations have significant undesirable impacts on the natural environment through local and global environmental pollution. Emissions of air pollutants such as Carbon monoxide (CO), Nitrogen Oxides $\left(\mathrm{NO}_{\mathrm{X}}\right)$, Carbon dioxide $\mathrm{CO}_{2}$, Sulphur Oxide $\left(\mathrm{SO}_{\mathrm{X}}\right)$, Hydrocarbons (HCs) and Particulate matter (PM), contribute to local air pollution, which has detrimental human health effects. Transport activities contribute approximately 29\% 


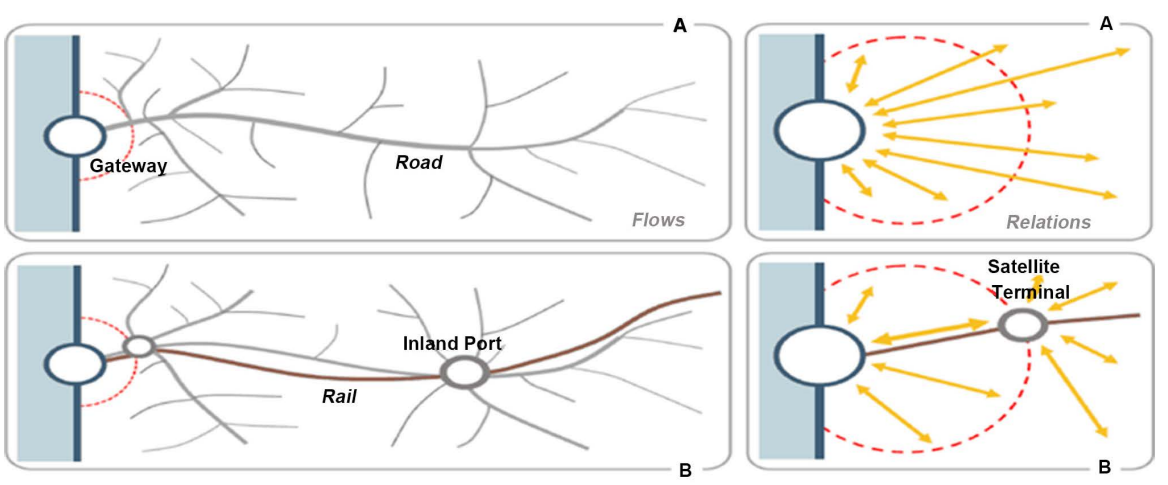

Figure 1. Modal shift and inland freight diversion before (A) and after the insertion of an inland port and satellite terminal [11].

of man-made Greenhouse gases-mainly $\mathrm{CO}_{2}$ - which promotes global warming [11]. Port infrastructure and operations are also harmful to the environment because they could lead to the modification of water systems and interference with the hydrological processes [13]. Noise pollution from port operations like intensive truck traffic and machinery operations affect the surrounding areas.

\section{Roles of Dry Ports in Transport Chains}

As shown in Figure 2, dry ports have a function-based hierarchy. Cargo transportation terminals exist within a hierarchical order with an integrated inland transportation system of gateways and their associated corridors, usually anchored on the function they serve within the chain. These freight terminals mainly serve as satellite depots (A), load centers (B) and trans-loading facilities (C) [11]. The services offered at the inland terminals are not exclusive, hence they can simultaneously serve several functions. For inbound or outbound cargo flows, the inland terminals are the first points in the functional hierarchy that clearly defines the fundamental and extended services offered to the hinterlands.

Satellite centers (A): These are close to a port facility, usually a distance of less than $100 \mathrm{~km}$, but at the outskirts of the metropolitan region. These centers accommodate additional port traffic and serve functions that are either too expensive at the port like empty container depots and warehousing services, or that which are less bound to a locations near deep sea quays. Most satellite terminals only serve a transportation function, being involved only in transshipment of cargo from barge or rail on to trucks and vice versa. Others may have additional function, serving as load centers for local or regional markets for economically dense areas. To serve this functionality, a multi-terminal grouping between the main port and these terminals are formed, connected through regular rail and/or barge shuttle services. These terminals can also serve a trans-loading function for gateways which have strong importation components, trans-loading the cargo in maritime containers to domestic containers [11].

Load centers (B): These intermodal facilities provide access to regional markets serving production and consumption functions. Load centers corresponds a 


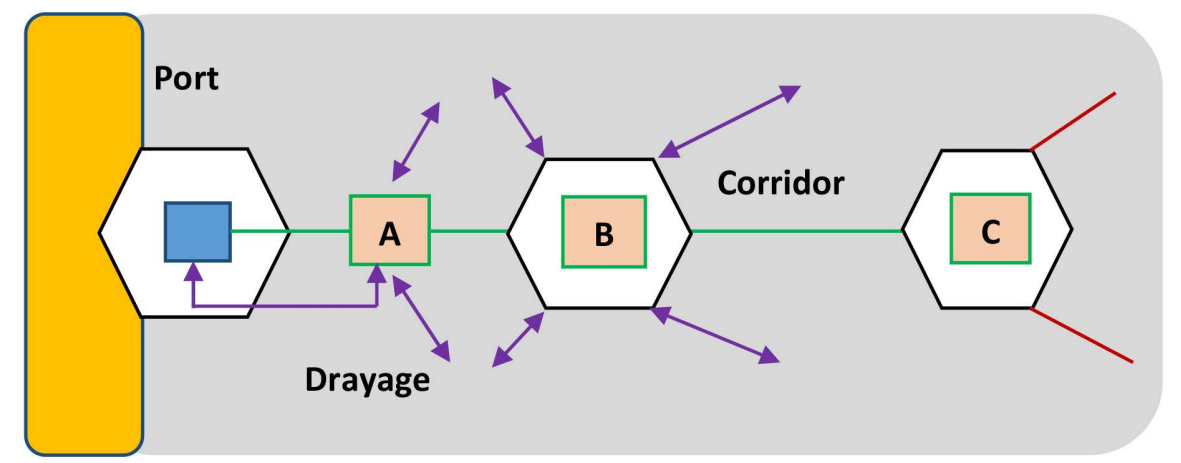

Figure 2. Functions of inland terminals [11].

metropolitan areas which serve warehousing, intermodal, distribution as well as logistics functions. Usually, this takes place in free trade zones, logistics parks and foreign trade zones. Therefore, at the inland terminals, there is collection or distribution for regional markets [11].

Trans loading facilities (C): They link large systems of cargo distribution through a similar mode e.g. rail-to-rail or through intermodal systems involving rail-to-truck or rail-to-barge. In case of the intermodal system, the inland terminal takes the role of a load center. These facilities are also similar to trans-shipment hubs in maritime shipping networks, because the origin or the destination of the cargo handled is outside the terminal's market area [11].

\section{The Function of Dry Ports within Supply Chains}

The five criteria that ensure that dry ports can effectively fulfill their roles within the supply chains as interfaces between global and regional freight distribution systems are; site and situation, repositioning, cargo rotation, trade facilitation and governance [11].

Site and location: Good access to rail or barge terminal with availability of ample land for development is a main factor considered while locating a dry port. Access to a large population base also greatly influences the choice of the location, because it has a direct relationship to the level of imports and exports handled at the inland port. A good transport network is also important, because it ensures accessibility of the inland port, which enhances the freight functions of the inland port.

Repositioning: Usually, both long distance and some domestic trade activities are supported by containerization. There cases where a regional market could be importing more than it exports and vice-versa. Here, an inland port has to provide the physical and logistical requirements to ensure that all empty containers are efficiently repositioned to other markets if there is unavailability of local freight. This can be effectively achieved by having empty container depots and making necessary arrangements with freight forwarders to avail repositioning slots.

Cargo rotation: At the inland port the inbound and outbound container flows must be quickly constantly reconciled. A common approach involves cargo 
rotation from import activities, where containers are transferred to export and filled with cargo. A speedy turnover of containers is essential and will guarantee a proper use of the inland port. Through effective repositioning and cargo rotations, higher revenues for both the container owners and the dry port operators can be ensured.

Trade facilitation: For small businesses that are unable to achieve economies of scale on their own, an inland port could promote both the import and export activities. Dry ports offer hinterland massification opportunities that are associated with reduced transport costs and improved accessibility, thereby increasing potential of new market opportunities fueled by relatively cheaper imports and exports.

Governance and management: The ownership and operation of a particular dry port can indicate the port's potential in identifying new market opportunities and can offer a clear guidance on how to invest accordingly to maximize the benefits from the dry port. A private investor, for instance, a port operator or a real estate developer can offer a good strategy in risk mitigation. Such investors can also provide the required expertise in development of facilities and running of the associated activities. Some sections of this facility could be shared e.g. distribution centers, and this could encourage the involvement of smaller players through renting equipment and space. A dry port facility can be owned as managed as a public, private or a public-private entity. Investment in dry ports is unlikely to be profitable within the first initial years, and therefore present a high risk to the private investors. However, they are perceived as being very beneficial to the public through creation of jobs. They also offer and option in ensuring better utilization of regional transport infrastructural facilities. A summary of the governance models is shown in Table 1.

\section{Dry Ports in China}

The high transactional and inland transportation costs coupled with a desire to move the benefits of containerization as deep as possible into the inland from the seaport, greatly influenced the initial development of dry ports in China. China has experienced unparalleled trade expansion over the past few years and therefore, there is an increase of goods from China destined to different parts of the world. An example is the China-US trade, where more than $60 \%$ of the total transport costs are attributed to transporting containers to and from the seaports. Therefore, dry ports are crucial in the supply chain, since they can offer improved operational efficiency and a reduction in total supply chain cost [7] [14]. To improve local economies in the western region of china, the Grand Western Development (Go West) strategy was introduced in 2000 [14]. This, was therefore another major motivation to the development of inland ports in China.

Logistics cluster forms the basis of dry port development by encouraging trade flows through funneling them into specific corridors. This encourages the scale of economies by means of cargo inflow concentration and consolidation [15]. 
Table 1. Governance models for dry ports.

\begin{tabular}{cll}
\hline \multicolumn{1}{c}{ Model } & \multicolumn{1}{c}{ Model characteristics } & \multicolumn{1}{c}{ Potential Implications } \\
\hline Single ownership & $\begin{array}{l}\text { A public or a private actor entirely responsible for development } \\
\text { and operations. } \\
\text { Single vision and conformity to a specific role. }\end{array}$ & $\begin{array}{l}\text { A single mandate characteristic makes it lack flexibility } \\
\text { in view of changes. } \\
\text { Potential conflicts with surrounding communities. }\end{array}$ \\
$\begin{array}{l}\text { Public-Private } \\
\text { Partnership }\end{array}$ & $\begin{array}{l}\text { Help combine public planning of infrastructures with private } \\
\text { operational expertise. } \\
\text { Public interests are well represented. }\end{array}$ & $\begin{array}{l}\text { Tendency to prioritize public interests over private } \\
\text { interests. }\end{array}$ \\
Landlord model & $\begin{array}{l}\text { Public ownership and private operations. } \\
\text { Long term concession agreements. }\end{array}$ & $\begin{array}{l}\text { Managerial flexibility between the owner, site managers } \\
\text { and operators. } \\
\text { The private operators usually assume most of the risk. }\end{array}$ \\
\hline
\end{tabular}

This principle of logistics cluster encouraged competition among the seaports in China and hence forced seaports to change their business strategies. The continuous growth of intra-regional port competition forced seaports to look for business opportunities at the hinterlands of their competing ports. This meant that a deeper hinterland connection was a vital strategy in this competitive environment [4]. The increased port competition also exposed seaports to "hub hopping", which involves "footloose" shipping companies moving their business to other terminals or ports and offering better business terms. This called for all the ports to be competitive in their entire operations including at hinterlands. To improve delivery of services at the hinterland terminals, the seaports in China use the dry ports as "extended gates" for the seaport, through which freight flows can be managed better [16].

Climate change mitigation is currently a global concern and there is the possibility that international companies aiming at reducing carbon footprints within their supply chain could lead to additional pressure on suppliers in China to engage in environmentally sustainable shipping and freight distribution. A good logistics network design should take the environmental impact into consideration and ensure that both the logistics costs and emissions are simultaneously reduced [17]. Although over 95\% of land-based container movements in China are done by road trucks [18]. However, rail and intermodal transport concepts have the potential of yielding significantly reduced emission levels [19].

According to Roso [20], dry ports have the potential of reducing carbon emissions by $25 \%$. This realization led to incorporation of environmental protection into the China's "go west" strategy. Dry port development has the potential to offer emission reduction benefits and still provide the required support to economic growth [21].

China's logistics regulatory system can be described as being fragmented, because there are varying policies at each level of government, that cover project aspects like funding, land planning, concession structure, licensing, inland customs clearance protocol and taxation. The development of logistics institution in the development of dry port in china can be said to follow the dual leadership principle led by the local governments. This could be attributed to the fact that the central government has come to appreciate the disadvantages of excess con- 
trol on project executions, which could results in an increased distance between the operational and decision making units [22].

According to this principle, the Central Government is one of the many stakeholders in the industry, as while the local Government, is engaged in more active roles in general logistics development. Figure 3 shows the institutional framework for the dry port industry in china. As shown in the figure, the framework follows a top-down approach, with a three-tier governance structure; central-provincial-municipal [23]. This industry is complex and diverse and requires appropriate strategy so as to make it possible to reduce this complexity especially in management. To achieve this, China's central government has tasked various ministries and appropriate agencies to deal with policies and financial affairs of each specific sector. The logistics sector involves the Ministry of Transport (MOT), Ministry of Railways (MOR) and the Ministry of Foreign Trade and Economic Cooperation (MOFTEC). The role played by customs is vital in this industry and hence, it has been allowed be a stand-alone department. Several municipal governments in china are directly overseen by the central government. Thus, both provincial and municipal governments can be classified as "local governments" without loss of the intended meaning in this paper.

A concession policy is an invaluable tool that can be used by local governments to achieve the development of dry ports. It is can also provide a way out for countries where private ownership of certain infrastructural assets is not allowed. In China, concession policies are useful to local governments that would wish to include the participation of the private sector in dry ports development, and still have total control of the these vital infrastructural assets.

The local government is a major player in this industry, and still retains the major role of nominating border crossing points Qingchen Zeng et al. [8]. Although there are very few private sector companies that directly invest in dry ports, there are quite a number of them that participate in operations of the dry ports through concession agreements. In the China, an operating company can take various forms including; a Local Port or Export Processing Zone administration committee, a state-owned inland port company or a privately owned logistics company.

\subsection{Motivations for Dry Port Development in China}

Since there is direct rail connections to seaports in China, dry ports reduce reliance on higher-cost truck services for inland transport [5] [24]. The mass transport capability of rail also relieves road congestion around the port and reduces the effect of local traffic bottlenecks and accidents [4] [24] [25]. This benefits shippers with faster lead times and fewer disruptions. Increased use of rail can also reduce air and noise pollution [24]. From a more strategic point of view, dry ports present ways of improving service to shippers, regional economy growth, and generate new employment opportunities [25]. The factors that have been key in motivating dry port development in China can be summarize as: 


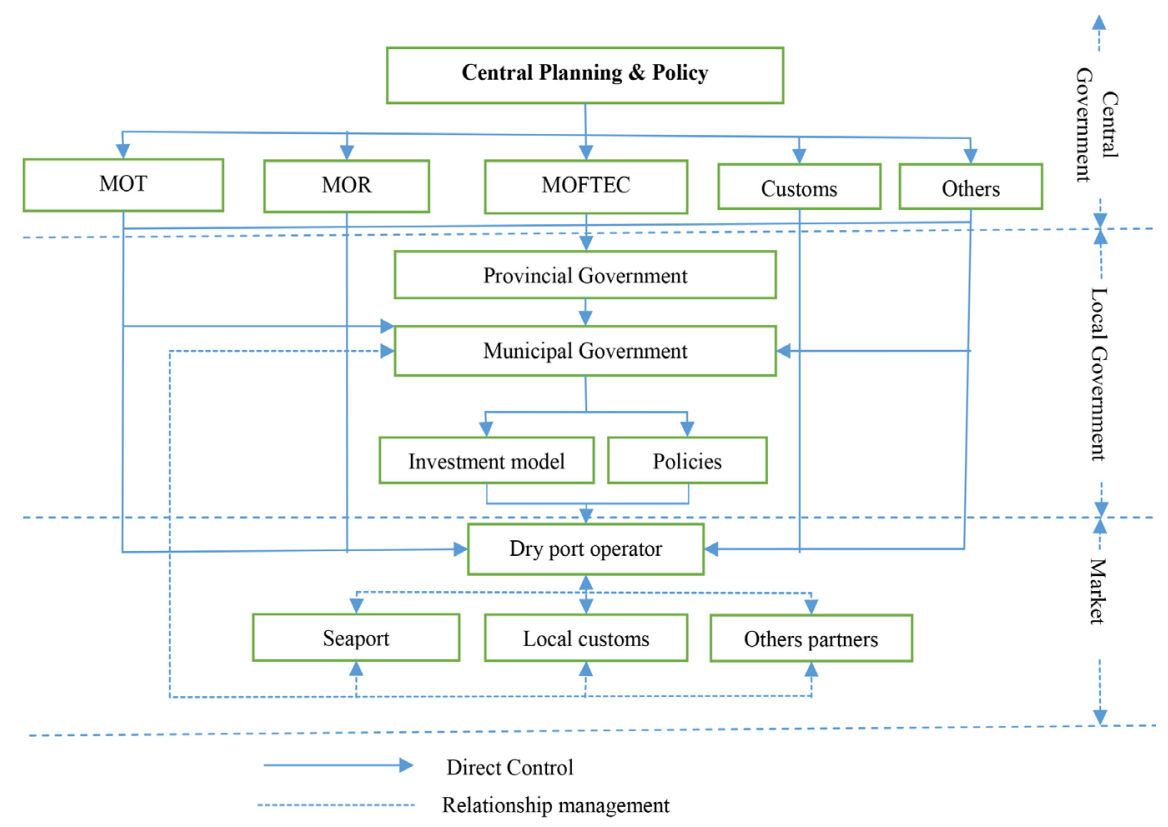

Figure 3. Institutional framework of China's dry ports [26].

1) Capacity and competition, 2) "Go west" strategy, 3) Reduction of logistics' cost, 4) Inland consumption, 5) Environmental sustainability.

\subsection{Development Modes of Dry Ports in China}

Two modes of dry port developments are applied in China, depending on the motivating factor influencing the need for a dry ports and the location of a particular port. Most dry ports in China were developed to meet the ever increasing supply chain needs which were in line with national interests. Dry ports were also developed to gain competitive advantage for the hinterland by respective local governments through the local ports.

Based on these factors, the first mode of dry port development in china is a joint venture between the Local governments and Seaport operators. These operators are mainly state-owned establishments in collaboration with China Railway Corporation. The collaboration is aimed at generating a new independent entity/company that undertakes the management and operations of the dry port. Examples where the joint venture model has been applied are the dry ports around Ningbo seaport such as: Yiwu, Quzhou, Shaoxing, Jinhua and Yutao. These were constructed in partnership with the respective city governments and Zhejiang provincial government.

The second development model is by use of the backland local governments. These plan, establish and manage infrastructural development supported by the China Railway Corporation. The main reason for application of this model in dry port development is to gain competitive advantage in domestic supply chain and to the improve welfare of the local population. One such example where such a model was used is the construction of a dry port in Shaanxi province in 
2010 aimed at linking the supply chain between the landlocked western China region and Sea ports in the Eastern region. After construction, home grown companies can be picked to operate and control the dry port or a new company could be created in collaboration with the railway or sea operators.

\subsection{Management of Dry Ports in China}

Dry ports in china are managed according to the public management model. Private companies rarely invest directly in dry port development, but rather are mainly involved in the operation of these facilities. Contrary to the prevailing situation in East Africa, where most of the port activities are usually outsourced, dry ports in china only outsource transportation of containers by rail and maintenance of railways wagons to China Railway Corporation. All the other activities performed by the port management or ownership. These activities include, transportation of containers within dry ports, the transportation of containers by road, cargo stuffing and un-stuffing and door-to-door delivery or pick up to inland container depots. In addition, the port management or ownership carries out the following; cargo consolidation and deconsolidation and container repairs. Value adding activities such as, fumigation, repacking, palletization, labeling and bar-coding are carried out by the management or ownership.

\section{Advantages and Disadvantages}

Since the ports are owned by local governments and operated by homegrown companies, the infrastructural investment is big and quick. The real investment figures for dry port developments in china are not fully accessible to the public, however, the rapid growth of these facilities in itself is enough evidence of the massive investment channeled towards these developments. The public management model also provides an opportunity to balance between profitability and national interests. Furthermore, the profits generated from these dry ports can be reinvested.

Development ventures that are fully owned and managed by governments or the public may encourage in efficiencies and corruption. There is also the possibility that some investment in dry ports may be politically motivated, therefore some may be developed in locations where they are not necessarily needed. This could be an avenue for misallocation and resource wastage that could have been used to address more pressing needs. Lastly, this model may result to coordination and management challenges and could, therefore, bring about negative impacts on efficiency in operations. This is because such a model creates a huge and complex institution with very many activities and employees.

\section{Ports in West Africa}

West Africa is majorly made up of developing countries some of which have sea ports like Nigeria (Apapa Lagos), Ghana (Tema and Takoradi), Togo (Lome), Ivory Coast (Abidjan), Benin (Cotonou) and Senegal (Dakar), and a number of landlocked countries; Mali, Burkina Faso, Chad and Niger. Similar to many sea 
ports in Africa, the sea ports in the West Africa have suffered from underdevelopment, inadequate port infrastructure, congestion and inefficiency. However, the ongoing economic rise in China has raised both interest and investment in African infrastructural projects, providing West Africa and Africa as a continent with access to huge capital that it has historically been unable to accumulate or obtain from other world financial markets [2]. This is evident from the surge of massive infrastructural investments in ports and intermodal development witnessed recently. For instance, the Tema port expansion to be completed by 2019 at an estimated cost of USD 1.5 billion, the Accra-Tema motorway at an estimated cost of USD 200 - 300 million, Nigeria's Lekki deep sea port, renovation of $645 \mathrm{Km}$ of road in Senegal and the modernization of Port of Lome in Togo [2]. These represent just a few of the ongoing projects that are expected to elevate West African to a position where it can command a larger share of the regional and wider shipping markets. Although the expansion and modernization of port facilities in the region will undoubtedly improve shipping capacity and turn-around time, in addition to reducing dwell time and evasion, developing better transport links to and from the seaports will be an equally important part of ensuring a brighter maritime future in the region. As shown in Table 2, it is evident that for long inland cargo haulages, roads are the dominant transport modes available in this region.

\subsection{Dry Ports in West Africa}

West African countries are characterized by long road cargo hauls within the countries with seaports and also across the landlocked countries. Although the concept of dry ports and their importance in reducing logistics costs, reducing emissions which pollute the environment, among others, has been introduced in this region, its implementation seems to face challenges, especially from lack of financing and underdeveloped intermodal infrastructure facilities. In fact only a few dry ports exist along the transport corridors of these countries, for both countries that have sea ports as well as those that are landlocked. Some of the operational dry ports along the transport corridors in West Africa include; Dakar port Logistic platform in Senegal, Bobo Dioulas so in Burkina Faso, Zongo and Allada in Benin as well as Kaduna in Nigeria. Some governments in these regions have also engaged financing and development partners to develop dry ports along the transport corridors and enjoy the fruits that come along with the availability of these facilities. A case in point is Dosso dry port in Niger, Parakou in Benin and Boankra in Ghana. Figure 4 shows the locations of Bobo-Dioulasso, Dosso and Para Koudry ports along the Abidjan-Dori and Cotonou-Dori transport corridors. The motivations for the development of most of the dry ports in West Africa are; to bring shipping services to the door step of shippers across the specific seaport countries, assist in decongesting the seaports and make them more user friendly, simulate the revival and modernization the railway as a primary mode for long distance haulage across West Africa, help in 
Table 2. Major transit corridors in West Africa [27].

\begin{tabular}{ccc}
\hline Corridor & Distance (KM) & Transport mode \\
\hline Dakar-Mali & 1250 & Rail \\
Abidjan-Burkina Faso-Mali & 1200 & Multimodal (Rail/Road) \\
Tema/Takoradi-Burkina Faso-Mali & 1100 & Road \\
Lome-Burkina Faso-Niger/Mali & 2000 & Road \\
Cotonou-Niger-Burkina Faso-Mali & 1000 & Multimodal (Rail/Road) \\
Lagos-Niger & 1500 & Road \\
Port Harcourt-Chad & - & Road \\
Lagos-Niger-Mali \& Lagos-Chad & 8000 & Multimodal (Rail/Road) \\
\hline
\end{tabular}

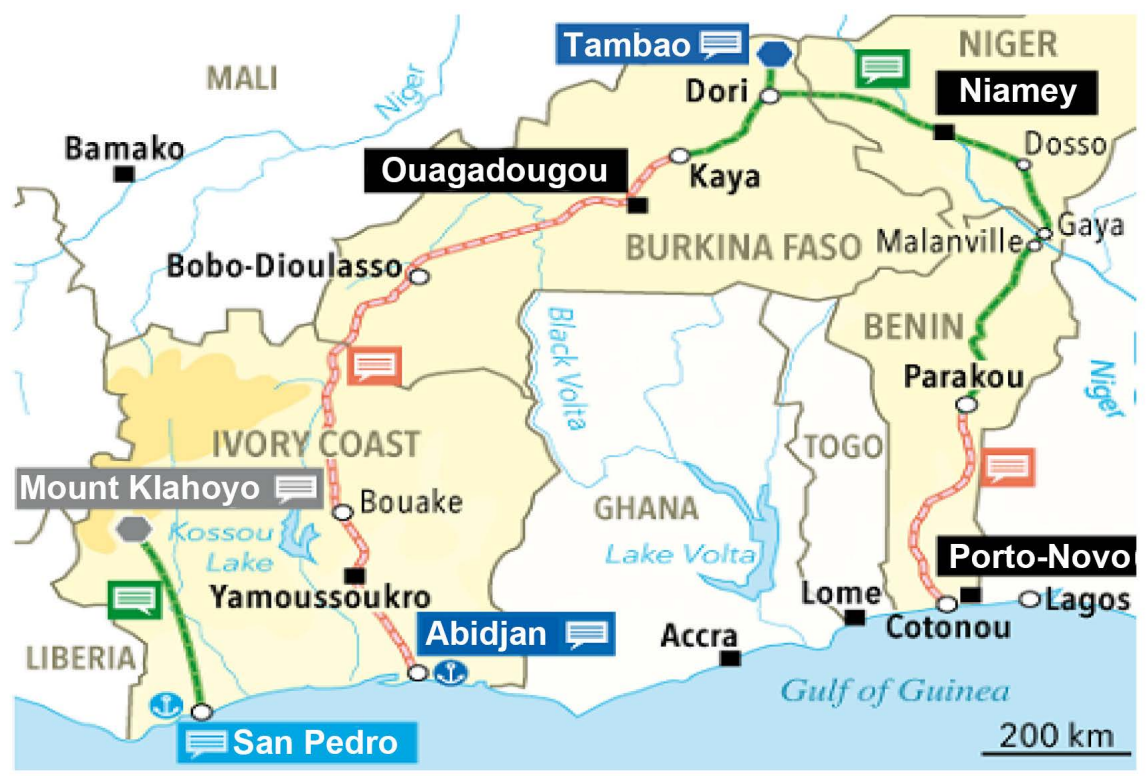

Figure 4. Locations of Bobo-Dioulasso, Dosso and Parakou dry ports [29].

the overall costs of cargo to hinterland locations as well as transit cargoes to landlocked countries among others [28]. The development and upgrading of the dry ports in West Africa are carried out based on the Public-Private-Partnership (PPP) and Build, Own, Operate and Transfer (BOOT) models.

\subsubsection{Motivation for Dry Ports Development in West Africa}

In West Africa, the motivation for development broadly varies depending on whether the country in question has a seaport or it is landlocked. For countries with sea ports, motivation for the dry ports would be to serve landlocked neighbors. Operations of dry ports in Nigeria, commonly referred to as Inland Clearance Depots (ICDs), started way back in 1979 in Kano and Kaduna in northern Nigeria under the management of Inland Container Nigeria Limited (ICNL) [30]. These dry ports were established as extensions to seaports to operate within the Nigerian Ports Authority guidelines, originally conceived to serve the hin- 
terland and its landlocked neighbors; Niger and Chad. In 2000, the Federal Ministry of Transport of Nigeria, acting on a recommendation of the Nigerian Shippers' Council, approved the implementation of a feasibility study for the establishment of dry ports at designated locations across the country [30]. The government responded to the report from the feasibility study by embarking on the implementation of these dry ports in a phased manner under the supervision of the Federal Ministry of Transport [30]. Apart from the Kaduna and Kano Inland dry ports there are about six other approved locations of inland Dry Ports around Nigeria that have already been concessioned to private sector operators by the ICDs Implementation Committee of the Federal Ministry of Transportation [28].

In addition, the ICDs are expected to achieve the following among others: 1) bring shipping services to the door step of shippers across the nation, 2) decongest the seaports and make them more user friendly, 3) provides the impetus to revive and modernize the railway as a primary mode for long distance haulage, and 4) assist in the over-all costs of cargo to hinterland locations as well as transit cargoes to landlocked countries.

On the other hand land-locked countries in this region rely upon the infrastructure and maritime access of their neighbors for their imports and exports. Niger, which is a land locked country relies on ports of Cotonou (Benin), Lome (Togo), Tema (Ghana), Abidjan (Côte d'Ivoire) and Apapa-Lagos (Nigeria). Consequently, Transport costs are prohibitively high, presenting a major challenge to Niger's economic development. To improve access to affordable trade, the Government of Niger $(\mathrm{GoN})$ made a commitment to develop dry port facilities and intermodal transport infrastructure along the key transport corridor [31]. To begin with, plans to implement dry port projects in Dosso and Niamey Rive Droite were established. These facilities are expected to: 1) facilitate international trade by strategic investment in multi-modal transportation infrastructure and promote value addition services to goods as they move through the supply chain, 2) hasten the flow of freight between seaports and major land transportation networks, which transport goods to the rest of the country, 3) achieve a reduced red tape and transportation costs for users in Niger, and 4) move the time-consuming sorting and processing of merchandise inland, away from the congested seaports in Benin, Togo, Ghana, and Côte d'Ivoire, its main accesses to the sea. These projects are overseen by a new Dry Port Authority established in 2014.

\subsubsection{Development Models for Dry Ports in West Africa}

A development model can be defined as a project delivery system describing method of combination and organization of design, procurement and construction services of a project in addition to operation, commissioning and maintenance which can be executed by the owner or other parties. It determines the appropriate sequence of the processes, contractual relationships and their area of obligations as well as commitments of the main parties that are involved in the 
realization of the project. The main difference between various types of project delivery systems is the distribution of risks among different players in the project [32].

West Africa dry ports are developed and upgraded based on two main models: Build, Own, Operate and Transfer (BOOT) and Public-Private Partnership (PPP). In PPP, private sector has a role as engineer or constructor. Ownership, operation and financing are the public role. On the other hand a pure private is responsible for all matter. In BOOT final owner is public, but concession for a long period of time ( 25 - 30 year) is regarded as private. The ownership shifts from public to private as we move from PPP to BOOT.

\section{Build, Own, Operate and Transfer (BOOT) Model}

A comprehensive definition of BOOT model was given by Barnet [33]. This model entails a government granting a concession of franchise to a private organization to build a specific facility, own it, operate and take the revenue generated from such a facility for a specific period of time and ultimately transfer it back to the central government [34].

Figure 5 shows a typical BOOT model contractual structure. Usually, at the center of this structure will be a project company or joint venture legally constituted in the host country. The project company, also called the promoter is normally a consortium and needs to establish contractual relationships over the period of the concession. In addition to the concession agreement with the host government, loan agreements with the banks, shareholder agreements with investors, off take agreements with the users of the facility, operation agreements with the operators and construction contracts with the constructors all need to be formulated. The consortium has the responsibility to construct and operate the facility, taking revenues generated until either the amount borrowed has been fully repaid or the period of the concession expires [35].

This model has been used in development of dry ports in Nigeria [36]. A case in point is the development of the Kaduna dry port which was commissioned in 2018 [37] and it's estimated that it will handle about 29,000 tons of containers yearly. The Kaduna Dry Port, which is the first of its kind in Nigeria, has been licensed to handle import cargo from Apapa Lagos seaport through the railway or road and also export goods through the same channel [37]. Apart from the Kaduna Inland Dry Port there are about seven other approved locations of inland Dry Ports around the country that have already been concessioned to private sector operators by the ICDs Implementation Committee of the Federal Ministry of Transportation.

\section{Advantages and Disadvantages}

The BOOT model is suitable and attractive to governments because, for one, it has a predictable and proven legal system. The model enjoys government support, since it is in the public interest and also provides a long term demand with limited competition as well as reasonable profits, predictable risk scenarios and good cash flows. In addition, it encourages maximum innovation giving rise to the most efficient designs, high accountability for the asset design, construction 


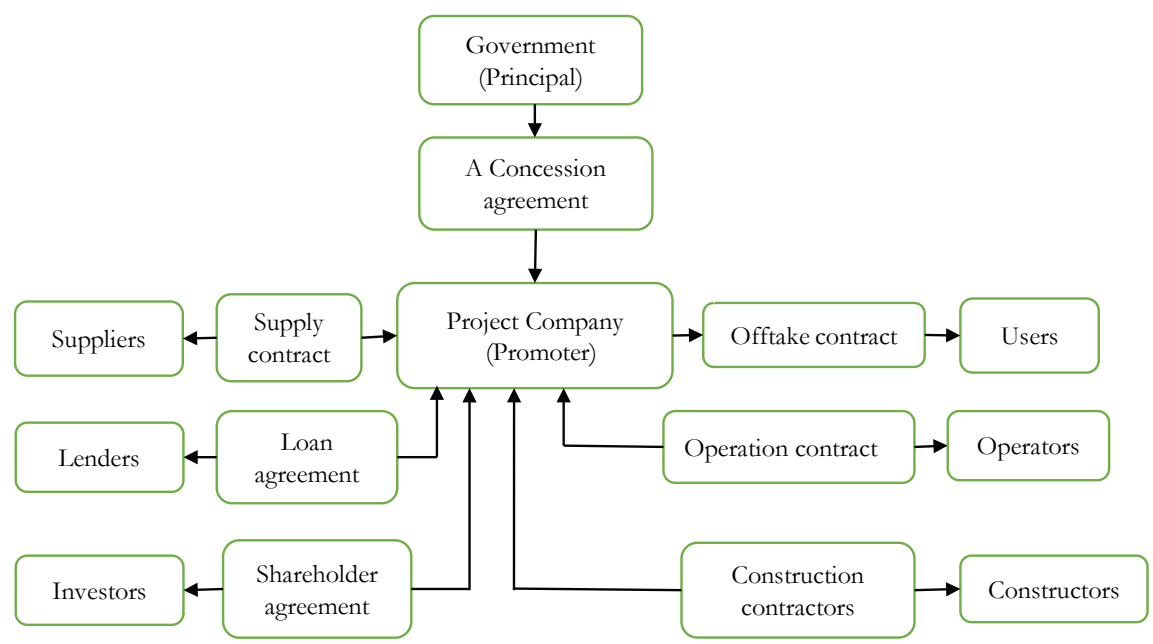

Figure 5. A BOOT development model [39].

and service delivery so as to recover the expenditures as well as enhancing management knowledge of the project through experience, hence minimal costs of company structuring matters.

This model may promote higher cost for the end user due to the BOOT provider accountability of 100 percent financing and on-going maintenance. There is also a possibility of negative reaction from the community to private sector involvement which could affect the delivery of the project. The model is time consuming and requires a lot of resources in management and monitoring of the operating contract with the BOOT operators as well as the requirement for a rigorous selection process in selecting BOOT partners [38].

\section{Public-Private Partnerships}

The Public-Private Partnership (PPP) model assumes a major portion of the responsibility for the delivery and the performance of the infrastructure under development, from the concept design, architectural and structural planning as well as its long term maintenance. Effective application of the PPP model can provide additional value to taxpayers by taking advantage of the right proficiency to complete the project on time and within budget. Consequently, a greater integration of project planning and design is possible, which eliminates major pitfalls as far as building, construction and maintenance of the infrastructure is concerned.

This model is a service contract between a public authority and a private sector concessionaire, where the public authority pays the concessionaire to deliver infrastructure and related services. Essentially, the concessionaire is financially responsible for the condition and performance throughout the project lifetime or the period of the agreement [40]. On the other hand, it can describe a government service or private business venture which is funded and operated through a partnership of the government and one or a consortium of private sector companies.

The Public-Private Partnership (PPP) model has been used by the government 
of Niger in the development of dry port facilities at Dosso along the Benin corridor and at Niamey Rive Droite along the Togo, Ghana and Côte d'Ivoire corridors [31]. With the assistance of Private Infrastructure Development Group (PIDG), a PPP transaction to deliver the dry ports in order to enhance access to affordable trade in the landlocked country has been developed [10]. This transaction structure is based on a 20 year concession agreement to invest in and manage the two dry ports. The dry ports are expected to be multimodal with a connection to a railways project between Port of Cotonou and Niger.

\section{Advantages and Disadvantages}

PPP engages in a competitive process to achieve the best value for money. This model transfers appropriate risks, establishes performance standards and payment mechanisms as well as maintaining government involvement in overseeing public interest. In addition, the features presented by this model improves project delivery, ensures better project discipline, while at the same time reducing scope creep and ensuring faster procurement [41].

This model has high costs associated with their implementation, both for the sponsoring government entity and for the private sector entities, improving the quality and clarity of tender documents, particularly with respect to the output specifications is required, Sometimes, there are not sufficient numbers of experienced private contractors to create the competitive tension required to achieve the best value for money, PPPs carry an implicit government guarantee and therefore should be priced as government risk This appears to be a philosophical objection about the line between what is privately provided and what the state should provide. Moreover, non-complete contracts and uncertainty over a long horizon are other PPP challenges.

\subsubsection{Management Models of Dry Ports in West Africa}

The landlord model is applied in the management of dry ports in West Africa in which concession is granted to an operator. It is characterized by Public ownership and private operations as well as long term concession agreements [11]. This reduces the financial burden in terms of funding such massive projects and hence, the governments can concentrate on the socio-economic welfare of the citizens. In addition, most of the African countries fall under the developing category, hence it would be a huge burden to apply a full public model in the management of dry ports. Managerial flexibility between the owner, site managers and operators. The private operators usually assume most of the risk.

\section{Conclusion}

In this paper, descriptive approach was used to carry out a comparative study of dry ports in China and the West Africa. The motivations behind the development of dry ports have been highlighted and discussed in details. Specific to China and West Africa, a comparative analysis has been carried out based on three parameters, i.e. the motivation behind the dry ports development, development as well as management models. It has been found that, although the mo- 
tivations behind the development of dry ports in the two regions differ, decongesting sea ports and reducing logistical costs are common to both regions. On development for dry ports, China uses two models: 1) depending on the reason of the dry port construction and the location of the particular port and;2) in order to gain competitive advantage for the hinterland by respective local governments. The first model involves a joint venture between the local governments and Seaport operators, while the second model is through backland local governments do the planning, initiate and manage infrastructural development supported by China Railway Corporation. In West African most countries use the PPP or the BOOT models. On management, dry ports in China use the public management model, as opposed to the dry ports in West Africa which are managed using the Landlord model. This study acts as a basis for future studies as more interest is shifted to the developing countries, which are in a race to develop their dry port facilities as well as the associate intermodal networks to enjoy the benefits of reduced logistical costs, reduced seaport congestions, increased port efficiencies, opening up their hinterlands as well as attaining environmentally sustainable infrastructural development.

\section{Conflicts of Interest}

The authors declare no conflicts of interest regarding the publication of this paper.

\section{References}

[1] FDT (2009) Survey on the Ports Cooperation. StratMoS Project, Work Package C-1, Interreg IVB Program.

[2] Ports West Africa (2017) State of West African Ports and Intermodal Projects: Expansion, Modernisation and Intermodal Construction. Ports and Intermodal West Africa, Accra, Ghana.

[3] Gerald, W.W. and Jin, Z. (2015) A Comparative Study of Dry Ports in East Africa and China. Developing Country Studies, 5, 7-17.

[4] Laveque, P. and Roso, V. (2002) Dry port Concept for Seaport Inland Access with Intermodal Solutions. Chalmers University of Technology, Gothenburg.

[5] Wang, C.H. and Wei, J. (2008) Research on the Dry Port Location of Tianjin Port Based on Analytic Network Process. 2008 International Seminar on Business and Information Management, Wuhan, 19-19 December 2008, 75-78.

[6] Nguyen, L.C. and Nottenbom, T. (2016) A Multi-Criteria Approach to Dry Port Location in Developing Economies with Application to Vietnam. The Asian Journal of Shipping and Logistics, 32, 23-32. https://doi.org/10.1016/j.jjsl.2016.03.003

[7] Beresford, A., Pettit, S., Xu, Q. and Williams, S. (2012) A Study of Dry Port Development in China. Maritime Economics and Logistics, 14, 73-98. https://doi.org/10.1057/mel.2011.17

[8] Qingcheng, Z., Michael, M. and Jomon, A.P. (2013) Dry Port Development in China: Motivations, Challenges, and Opportunities. Transportation Journal, 52, 234-263. https://doi.org/10.5325/transportationj.52.2.0234

[9] De Oliveira, L. (2008) European Coordinator for Motorways of the Sea-Priority Project 21 Fostering Seamless Transport in the European Union. Motorways of the 
Sea in the European Logistics Chain. Annual Report.

[10] PIDG (2015) PIDG Project Fact Sheet Africa: Niger Dry Port, PIDG.

[11] Jean-Paul, R. and Theo, N. (2012) Dry Ports in Europe and Northern America Inter-Modal Rail System: Two of a Kind? 5 th Asian Logistics Round Table and Conference, Vancouver, 14-15 June 2012, 1-23.

[12] Rodrigue, J.P. and Notteboom, T. (2011) Dry Ports and the Maritime Hinterland: Gaining Momentum. Port Technology International, 50, 21-24.

[13] Michail, A. (2006) Environmental Management of the Logistic Chain: Concepts and Perspectives. International Conference, Shipping in the Era of Social Responsibility, Argostoli, Cephalonia, Greece.

[14] Monios, J. and Wang, Y. (2013) Spatial and Institutional Characteristics of Inland Port Development in China. GeoJournal, 78, 897-913. https://doi.org/10.1007/s10708-013-9473-2

[15] U. A. K. M. Institute (2008) Logistics Sector Developments: Planning Models for Enterprises and Logistics Clusters. UNESCAP, Bangkok, Thailand.

[16] Ng, A.K.Y. and Tongzon, J.L. (2010) The Transportation Sector of India's Economy: Dry Ports as Catalysts for Regional Development. Eurasian Geography and Economics, 51, 669-682. https://doi.org/10.2747/1539-7216.51.5.669

[17] Aronsson, H. and Brodin, M.H. (2006) The Environmental Impact of Changing Logistics Structures. International Journal of Logistics Management, 17, 395-415. https://doi.org/10.1108/09574090610717545

[18] Johnson, I. (2011) Train Wreck in China Heightens Unease on Safety Standards. New York Times, New York.

[19] Leach, P.T. (2010) US Ports Grow Greener to Grow Deeper. http://www.joc.com/maritime/us-ports-grow-greener-grow-deeper

[20] Roso, V. (2007) Evaluation of the Dry Port Concept from an Environmental Perspective: A Note Part D. Transportation Research, 12, 523-527.

[21] Zeng, Q. and Yang, Z. (2012) Interviews with Managers from Sea Ports, Dry Ports, and Freight Forwarders between 2011-2012.

[22] Wang, J.J., Rong, C., Xu, J. and Or, S.W.O. (2012) The Funding of Hierarchical Railway Development in China. Research in Transportation Economics, 35, 26-33. https://doi.org/10.1016/j.retrec.2011.11.004

[23] Asian Development Bank (ADB) (2008) Transport Efficiency through Logistics Development Policy Study: People's Republic of China. ADB, China.

[24] Rahimi, M., Asef-Vaziri, A. and Harrison, R. (2008) An Inland Port Location-Allocation Model for a Regional Intermodal Goods Movement System. Maritime Economics and Logistics, 10, 362-379. https://doi.org/10.1057/mel.2008.17

[25] Roso, V. and Lumsden, K. (2010) A Review of Dry Ports. Maritime Economics and Logistics, 12, 196-213. https://doi.org/10.1057/mel.2010.5

[26] Pettit, S. and Williams, S. (2012) A Study of Dry Port Development in China. Maritime Economics and Logistics, 14, 73-98. https://doi.org/10.1057/mel.2011.17

[27] UNOHRLLS (2017) Africa Regional Report on Improving Transit Cooperation, Trade and Trade Facilitation for the Benefit of the Landlocked Developing Countries: Current Status and Policy Implications. http://unohrlls.org/custom-content/uploads/2017/05/AFRICA-REGION-REPORT7-June.pdf 
[28] Council, N.S. (2016) Dry Ports. https://www.shipperscouncil.gov.ng/inland-dry-port

[29] Pascal, K.P.G. and Yan, C. (2017) Challenges and Strategies of Abidjan Port-Hinterland Connectivity. EDP Sciences, 124, 1-7.

[30] Paul, G., Anthony, B. and Stephen, P. (2009) Dry Ports: Comparative Study of the United Kingdom and Nigeria, Transport and Communications Bulletin for Asia and the Pacific No. 78, 40-56.

[31] ESCAP (2015) Potential Project Structuring Options for Development of Dry Ports under PPP Mode in Asia-Pacific Region.

[32] Thomas, S.M. (2003) Measuring the Impacts of Delivery System on Project Performance. Construction Industry Institute.

[33] Barnet, M. (1987) Role of the Merchant Banker in Projects. International Journal of Project Management, 5, 197-203. https://doi.org/10.1016/0263-7863(87)90041-X

[34] Merna, A. and Smith, N. (1991) Concessions and Risks in BOOT Projects. Association of Researchers in Construction Management Annual Conference, Bath, 4-6 September 1991, 11-19.

[35] Confoy, B., Love, P., Wood, B. and Picken, D. (1999) Build-Own-Operate-The Procurement of Correctional Services. Profitable Partnering in Construction and Procurement Joint Symposium, London, 25-28 January 1999, 461-474.

[36] Council, N.S. (2008) Inland Container Depots. Nigerian Shippers' Council.

[37] Ships \& Ports (2018) Ships and Ports, Ships and Ports Editorial. http://shipsandports.com.ng/category/editorial/

[38] McCarthy, S. and Tiong, S. (1991) Financial and Contractual Aspects of Build-Operate and Transfer Projects. International Journal of Project Management, 9, 222-227. https://doi.org/10.1016/0263-7863(91)90030-Y

[39] Marcus, J.R.G. (2002) Critical Success Factors of the BOOT Procurement System: Reflections from the Stadium Australia Case Study. Engineering, Construction and Architectural Management, 4, 352-361.

[40] Lina, T., Kent, B., Michael, L. and Anthony, C. (2009) The Dry Port-Concept and Perspectives. The Interreg IVB North Sea Region Program, Aalborg, Denmark.

[41] Peter, O.P.B. (2010) Conferenz.

http://www.conferenz.co.nz/whitepapers/public-private-partnerships-and-new-zeal and-land-transport-projects 